\section{Towards Jamie Mccallum (Dir.), The Real Work}

The Real Work, directed and produced by Jamie McCallum, USA, 2016, 5.19 minutes, color

| Senka Anastasova

\section{Bionote}

Senka Anastasova (Institute of Social Sciences and Humanities - Skopje) is an Associate Professor of philosophy, cultural studies, feminist politics, film studies. Doctor of social sciences, a socialist feminist, a philosopher, and author of the books (in Macedonian): Narrative Identities and Political concepts: Christa Wolf and Dubravka Ugrešić (2007) and Theory of Popular Culture: Introduction to Cultural Studies (2012). In 2006 she was a winner of The British Scholarship Trust's Voya Kondic Memorial Prize.

Institute of Social Sciences and Humanities - Skopje

senka.anastasova@isshs.edu.mk

The Real Work by Jamie McCallum opens with an illuminative and suggestive narrative - how daily low-waged hard work reflects on people's life in America today. Unfolding into a short period, this film shows an effective way to understand the social labor and how capitalism is affecting common working people. Behind the plot present, the social context is America after the global economic crises, rapidly exposed to the capitalistically organized forms of social reproduction and over-accumulation. The main provocation for making this video essay is rising questions about asymmetry of power that currently exists between labor and capital. One of the core effects of labor critique is to develop hegemonic equilibrium between the strength from below and above, between the power of employer and employee in particular jobs, to increase wages, to improve working conditions against exploitations, especially with focus on different forms of work - those that are unpaid, degrading, dangerous, low-waged and unattractive.

The Real Work's framing of current and complex American economic context is not just left at the metaphorical level, somewhere behind the represented. The Real Work is a thoughtful, documentary film by Jamie McCallum that opens a new way of thinking about work in the social economy sector and capital accumulation in America today. Compared to other social justice documentaries from 2016/2017 this film establishes a narrative line that is related to critically rereading the context of political economy - specifically not through grand economic narratives of history, but through personal focalizations and experience of few people: workers, diggers, real flesh and blood subjects and their stories.

At the beginning, the audience is easily involved into the personal standpoints of the 
subjects. I am going to present the "political" and "economic" views from this film, through three diggers "voices". The first digger is a carpenter (see Figure 1). He says that one could

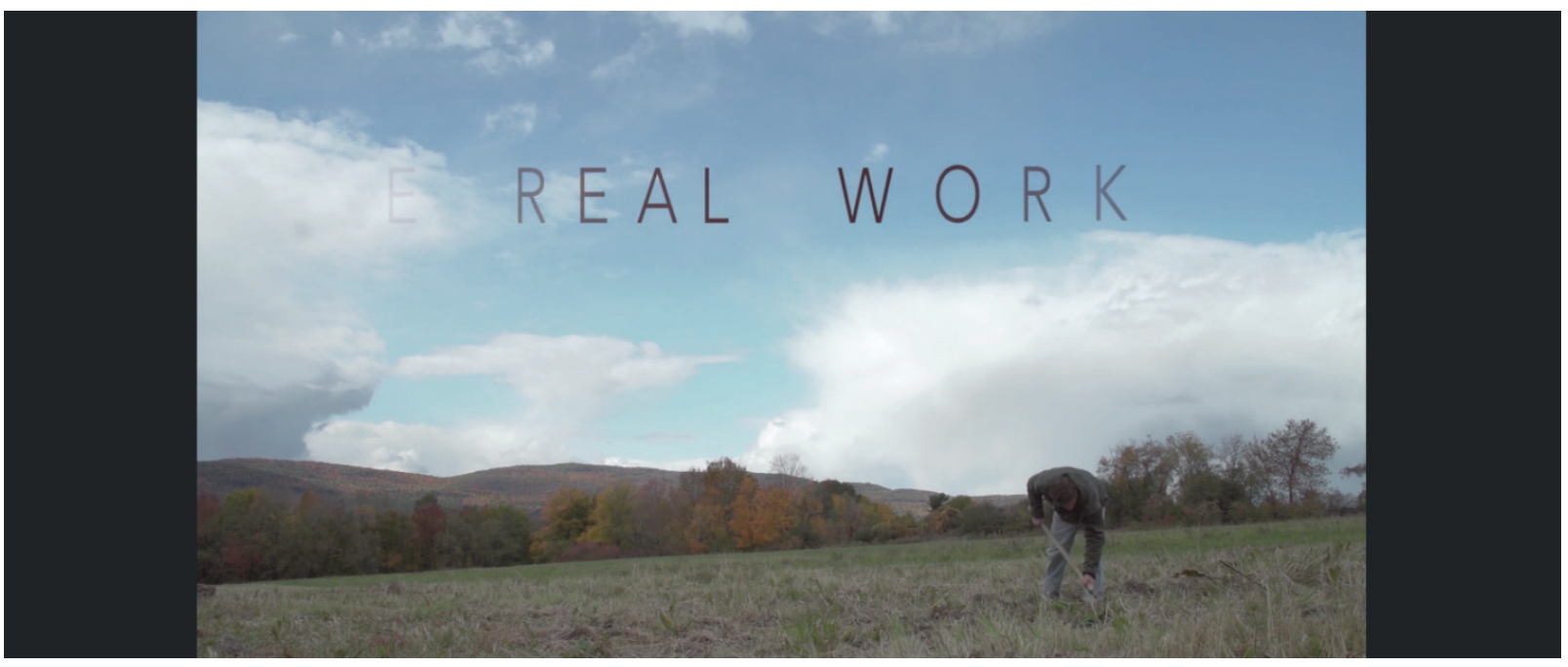
not go away from the projects when the job comes and one is not in the position and does not have an option to reject the job when it comes, even if he does not like it. The second digger says that the point of work is not to do what you love, but to support yourself, to be able to make for a living. The third digger is a woman, she is a personal care attendant. She works hard to survive with a low paid job. She feels like she is hurting herself and her family. Through her we see the direct state of body discipline in capitalism and the forcing of the body in economic terms of utility to be productive, but at the same time to be a subjected body. She finds working for a low paid job meaningless, but she is thankful that the job she has been doing means more to someone else than it does to her.

Figure 1. Scene from The Real Work.

The body of the worker(s) as an artefact is important in this film, at socio-political and cultural level of interpretation; it is extended outward from each worker. J. McCallum is focused on the idea of the "body of the worker" as political and economic semantic field of the sign that designates the body in the specific social group in society (that is, the group of manual workers, health care workers). In sociological and culturological sense, when listening to the third (female) digger, we see her (see Figure 2) trying to find the reason for doing low paid hard work, while she is split between herself and her family. Here, one of the basic implicit questions that McCallum opens through her is how the concept of the body mat- 
ters for the labor theory against capitalism? In socio-culturological context, the body of the worker in this film feels society's pressure; it is used to fill the gaps of non-sense of doing exploitative hard work. The third female narrator is moving her body, digging, while talking about the need to work, to earn for life. This scene represents the social body whose movement is regulated by society's system of authority, understood in the sense as posited by Foucault ${ }^{1}$; this female body replaces the whole pain inside her by using her physical body to work for life. The focus here is on the strengthening of the idea about the body - out of the physical capacity of doing the hard work. This scene is one of the most powerful in the film. work here is understood as a "punishment" that has to make

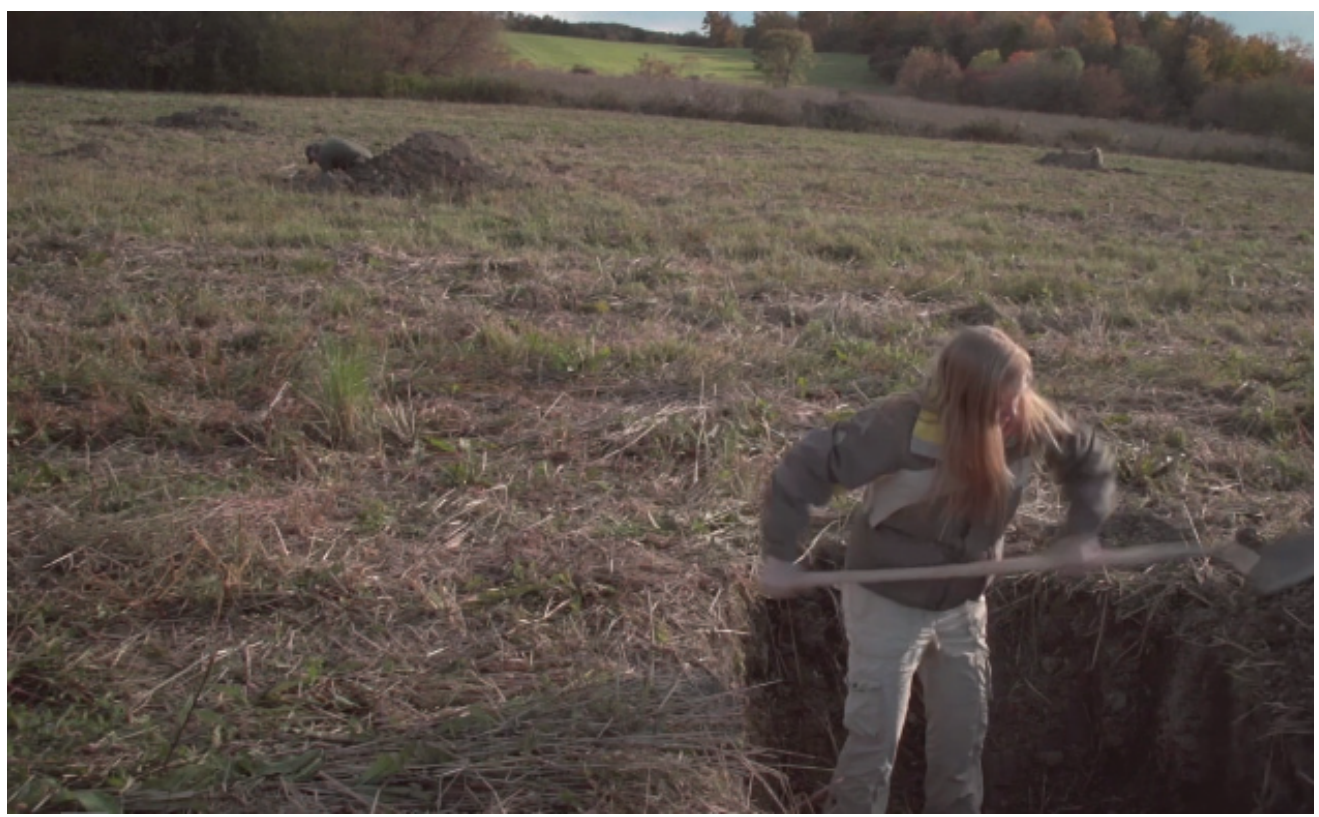
use not only of the (female) body for low paid work, but of the economic representation of the society, because that body is not so much the subject of pain but the object of a representation. As anthropologists discover subjects that are exploited, established in the visual sociological forms, this scene opens the core talk ${ }_{1}$ Michel Foucault, Discipline and Punish: The Birth of the Prison, trans. by Alan Sheridan (New York: Vintage Books, 1991), 130. about wage, and thus makes the work visible. ${ }^{2}$ The Real Work redefines the terrain of socioculturological and economic determination of the body, while at the same time it shows how doing (hard) work is the way to be included into the legitimate protocols of visible labor in society.

Figure 2. Scene from The Real work.

At visual-technical level, this documentary is opened to the critical thinking of the film diegesis in socio-culturological context. Jamie McCallum makes the relationships between all workers, he deals with the de/framing of

2 Silvia Federici, Wages against Housework (Bristol: Power of Women Collective and Falling Wall Press, 1975), 5. 
their voices and it is in this way that he builds his specific aesthetics and politics reception effect to the audience. Hence, the radical act in this video essay is that J. McCallum spreads the radical critique of the current capitalist society in a way that he takes the economic plot from the empiric frames in American economic society, and puts in subjects/ actants/workers/diggers with no pretentions to show what is "real," but to follow the personal and emotional commitment of the workers. Jamie McCallum points to the low wage hard work as the "Real," that is, "traumatic experience,"3 and we are unable to integrate it in our daily reality when we say "real". That is the power of his expression.

The Real Work actualizes Marxist and post-Marxist interpretations in contemporary political theory; Jamie McCallum is sensitive to the dissensual politics that defines itself through the perceptual matrix of social theory of labor, in a way that suspends neoliberal forms of domination and enters a "radical democratic" terrain of labor via giving space to the voices of resistance. The subjects in The Real Work are auctorial, which means that $\mathrm{J}$. McCallum has left the plot to unfold through them in the focalization diegesis, without the author's interventions. These diggers are im-

\footnotetext{
${ }^{3}$ Slavoj Žižek, Welcome to the Desert of the Real (London and New York: Verso, 2002).
}

pressive witnesses of the fury of the history of precarious work, longing for basic labor rights. For some of the workers, doing hard work is a central aspect of their identity, for others shoveling dirt in an empty field reminds them of others, jobs they found socially useless, meaningless, or degrading. In the depth of every narrator's/digger's voice lays the understandable anger of Jamie McCallum, mixed with sepia toning, on low paid jobs, as just another day of bare survival.

Cultural studies, political theory of cinema and political sociology syllabi could take The Real Work as documentary related to the interpretations of the "libidinal economy" of the "holes". The spectator follows the idea that doing hard work is symbolically showed, via digging holes. The students in cultural studies and political sociology could discuss the "holes" in this film as a proto-base that could open the question: Does working a hard job today leads us to nowhere? Is the digging with no aim? Is it a ride without an answer? The question is: to dig, day in and out, until you are capable of doing it. To dig well, or to die.

Music in the video, sky, rainy cold weather, cold hands, the diggers' dry faces are some of the excellent cover frames for the atmosphere in the film. On the one hand, the film could be perceived ultimately as pessimism (as everlasting digging in the hole/the de-flated) 
rather than systematic organization and thinking against capitalist economic hegemony. On the other hand, The Real Work shows that holes could be spacious - they are made of space, they are created only by an action upon something; and are ontologically dependent entities (everything begins with a hole, vaginal birth, cosmic black hole; holes, as a matter of life). In this sense, The Real Work opens a cinematic door for a different interpretation of a hole, as a space between the human work and the landscape (society); or a hole as a connection to the very Land (as in Tarkovsky's movies, the Zone from Stalker); or, as a bridge between life and death (Jesus comes to Lazarus and orders him to rise from the hole). In a visual methodological-sense of social theory, the "holes"/"ruptures" show that they stay active, to be covered by the next method (an upcoming better society, for example). In The Real Work, the "hole" could be related to the vision of the future of labor's fights/rights, that one cannot be enclosed within any dialectical totality, or logical unity, ${ }^{4}$ between what one does, and what one can do, what one has or what one could have. Beyond the tired voices of workers, there is the voicing-over that sets up the main frame and coloring of this film, i.e., the

${ }^{4}$ Antonio Negri, Marx Beyond Marx: Lessons on the Grundrisse, trans. by Harry Cleaver, Michael Ryan and Maurizio Viano (New York: Autonomedia and Pluto Press, 1991), 12 . workers deserve to work with more dignity and respect for the jobs they are working; there is a moment in the film when the female digger says that the economy today leads people to be afraid of organizing themselves, but we need a change. The struggle against work is to produce time to have a life outside work, outside our jobs, to strength our community, which does not mean to erase the valorization of human activities which have escaped from labor's acts.

The Real Work by Jamie McCallum is an influential video essay that treats economy, unpaid work, social justice inequality, grasping the idea for organizing better conditions for work, regulation, protection of worker's rights, and change in anti-capitalist society in America today. This film would be important for productive analyses of social justice documentaries. Jamie Mccallum shows that "real" work stays beyond the monopolization of our lives, beyond exploited forms of waged work performed by workers in the United States, 5 beyond the uncertain economic future. While we are digging for our life, the life is happening somewhere else, it is outside the hard work, and we are longing to name it, in the dialectic of semblance. There is the "Real" that cannot be reduced to the "fact" into reality. This film should be part of social justice festivals in

\footnotetext{
5 Kathi Weeks, The Problem with Work: Feminism, Marxism, Antiwork Politics, and Postwork Imaginaries (Durham, North Carolina: Duke University Press, 2011), 13.
} 
America and Europe that treat unpaid work and anti-capitalism today. 